\title{
Relação peso-comprimento de peixes do rio Tarumã, drenagem do rio Machado, Rondônia, Norte do Brasil
}

\author{
Length-weight relationships of fishes from Tarumã River, Machado \\ River drainage, Rondônia State, northern Brazil
}

\begin{abstract}
da Costa ID, dos Santos Nunes NN. Relação peso-comprimento de peixes do rio Tarumã, drenagem do rio Machado, Rondônia, Norte do Brasil. Rev Colombiana Cienc Anim. Recia. 2019; 11(2):Articulo718. DOI: https://doi.org/10.24188/recia.v11.n1.2019.718

Universidad de Sucre, Colombia
\end{abstract}

Los autores permiten a RECIA reimprimir el material publicado en él. En caso de que un autor quiera traducir o usar una publicación parcial o completa de nuestro Diario, el autor debe obtener un permiso por escrito del editor de la revista.

Revista Colombiana de Ciencia Animal - RECIA está distribuido bajo una Licencia Creative Commons Atribución-CompartirIgual 4.0 Internacional. 


\title{
Relação peso-comprimento de peixes do rio Tarumã, drenagem do rio Machado, Rondônia, Norte do Brasil
}

\author{
Length-weight relationships of fishes from Tarumã River, Machado River drainage, \\ Rondônia State, northern Brazil
}

Igor David da Costa

DOI: https://doi.org/10.24188/recia.v11.n2.2019.718

igorbiologia@yahoo.com.br

(D) https://orcid.org/0000-0002-8556-5507

Universidade Federal Fluminense, Instituto do Noroeste Fluminense de Educação Superior, Avenida João Jasbick, s/no Bairro: Aeroporto, CEP: 28470-000, Santo Antônio de Pádua, Rio de Janeiro, Brasil.

Universidade Federal de Rondônia, Mestrado Profissional em Gestão e Regulação de Recursos Hídricos (PROF-ÁGUA), Campus Ji-Paraná, Rua Rio Amazonas, 351 - Jardim dos Migrantes, CEP: 76900-726, Ji-Paraná, Rondônia, Brasil. *Autor correspondente: igorbiologia@yahoo.com.br

\section{Natalia Neto dos Santos Nunes}

nataliansnunes@gmail.com

(D) https://orcid.org/0000-0001-5744-1358

Universidade Federal de Rondônia, Programa de Pós-Graduação em Ciências Ambientais, Av. Norte Sul 7300, CEP:

76.940-000, Rolim de Moura, Rondônia, Brasil.

Recepción: 30 Abril 2019

Aprobación: 18 Junio 2019

Publicación: 4 Julio 2019

\begin{abstract}
The length-weight relationship has many functions in the area of fish ecology. The objective of this work is to provide the estimates of morphometric relationships for 13 freshwater fish species. Samples were collected with the aid of gillnets in May and September 2015 in the Tarumã river, Jaru Biological Reserve. Length-weight relationships were estimated from 343 specimens belonging to thirteen species, seven families and two orders. The linear regressions were significant $(\mathrm{p} \leq 0.001)$. The value of $b$ varied from 1.36 in Leporinus friderici to 3.30 in B. amazonicus. The specie Colossoma macropomum had an isometric growth pattern $(b=3.09)$. The new Length-weight relationships for 2 species, new maximum weight for 4 species and maximum sizes recorded for 3 species highlight the scarcity of information on biological aspects of Amazon fishes. These results can provide information for the FishBase as well as important data for the management of icthyofauna and conservation of the Tarumã River Basin.
\end{abstract}

Keywords: Amazonia; biological reserve; Conservation; Biodiversity, Ichthyofauna 


\section{RESUMO}

A relação peso-comprimento tem muitas funções na área da ecologia de peixes. 0 objetivo do presente trabalho é o de fornecer as estimativas de relações morfométricas para 13 espécies de peixes de água doce. As amostras foram coletadas com o auxílio de malhadeiras, em maio e setembro de 2015, no rio Tarumã, Reserva Biológica do Jaru. As relações peso-comprimento foram estimadas a partir de 343 espécimes pertencentes a treze espécies, sete famílias e duas ordens. As regressões lineares foram significativas ( $\mathrm{p} \leq 0.001)$. 0 valor de $b$ variou de 1,36 em Leporinus friderici a $3.30 \mathrm{em}$ B. amazonicus. A espécie Colossoma macropomum apresentou um padrão de crescimento isométrico ( $b=3.09)$. As novas relações peso-comprimento para 2 espécies, novo peso máximo para 4 espécies e tamanhos máximos registrados para 3 espécies destacam a escassez de informações sobre aspectos biológicos dos peixes da Amazônia. Estes resultados podem fornecer informações para a FishBase, bem como dados importantes para o manejo da ictiofauna e conservação da Bacia do Rio Tarumã.

Palavras-chave: Amazônia; Reserva Biológica; Biodiversidade, Conservação; Ictiofauna

\section{RESUMEN}

La relación longitud-peso tiene muchas funciones en el área de la ecología de los peces. El objetivo de este trabajo es proporcionar las estimaciones de las relaciones morfométricas para 13 especies de peces de agua dulce. Las muestras se recolectaron con la ayuda de redes de enmalle en mayo y septiembre de 2015 en el río Tarumã, Reserva Biológica Jaru. Las relaciones longitud-peso se estimaron a partir de 343 especímenes pertenecientes a trece especies, siete familias y dos órdenes. Las regresiones lineales fueron significativas $(\mathrm{p} \leq 0.001)$. El valor de $b$ varió de 1.36 en Leporinus friderici a 3.30 en B. amazonicus. La especie Colossoma macropomum tenía un patrón de crecimiento isométrico ( $\mathrm{b}=3.09)$. Las nuevas relaciones Longitud-peso para 2 especies, el nuevo peso máximo para 4 especies y los tamaños máximos registrados para 3 especies resaltan la escasez de información sobre los aspectos biológicos de los peces del Amazonas. Estos resultados pueden proporcionar información para FishBase, así como datos importantes para el manejo de la ictiofauna y la conservación de la cuenca del río Tarumã.

Palabras clave: Amazonia; reserva biologica Conservación; Biodiversidad, Ictofauna

\section{INTRODUCTION}

The largest number of protected areas (PA) in the world is in Brazil (1), totaling more than 30000 $\mathrm{Km}^{2}$ (2). About 43\% of Brazilian Amazon are considered PA (3). Although there are doubts about the purpose of conservation units, studies indicate that these are useful in reducing deforestation and ichthyofauna conservation $(4,5)$.

The Amazon basin is home to the world's largest ichthyofauna diversity $(6,7)$. In the Madeira River basin, more than 820 species of fish were recently identified (8). In the Machado River basin, Madeira River sub-basin, 48 species were collected at the Pirarara and Tamarupa rivers (9), 140 species in small streams (10) and 74 species in the Tarumã river, middle Machado River (11). The studies on evaluation of fish stocks in the Amazon region are scarce (12), as well as information on fish morphometric relationships $(13,14)$.

The length-weight relationship (LWR) has many functions in the area of fish ecology (15). The LWR allows i) to predict fish length based on weight and vice versa, ii) calculate the growth rate of the species 
and iii) obtaining the body state of the individuals sampled (16). The LWR studies are necessary to understand the fish life cycle, especially in regions where fishing represents the important economic activities and the main animal protein consumed by traditional communities (12). The objective of this study was to calculate the LWR of 13 species of fish captured in the Tarumã River, Jaru Biological Reserve, as the first study on the biology of fish species in this PA.

\section{MATERIALS AND METHODS}

The Jaru Biological Reserve (Rebio Jaru) is administered by the Instituto Chico Mendes de Conservação

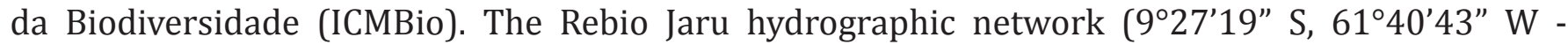
$9^{\circ} 47^{\prime} 04^{\prime \prime}$ S, 61 ${ }^{\circ} 40^{\prime} 19^{\prime \prime}$ W) is part of the Machado River basin, Rondônia State, Brazil. The Tarumã River is located in the Rebio Jaru area.

We performed collections of freshwater fish in May and September 2015. We collected the fish using a total of eight gillnets with meshes of $2 \times 20 \mathrm{~m}$ (mesh sizes: 30, 40, 50, 60, 70, 80, 90 and $100 \mathrm{~mm}$, opposite knots), these were euthanized in a solution of clove oil (17). The fish were fixed in $10 \%$ formalin solution, preserved in 70\% ethanol and later deposited in the Coleção de Peixes da UFMT, Brazil. The fish sampling was authorized by the ICMBio (license code: 48723-2/2015).

The individuals captured were identified with the help of identification keys (8) and biometric data (total length (TL) in $\mathrm{cm}$ and total weight (TW) in g) were recorded. Weight and length were estimated using the expression $\mathrm{P}=a \mathrm{C}^{b}$, where $\mathrm{P}=$ weight total, $\mathrm{C}=$ total length, $a=$ intercept and $b=$ angular coefficient (18 Le Cren, 1951); the parameters $a$ and $b$ were estimated after logarithmic transformation of weight and length data (19). We verified in the fishBase (20) the absence of the LWR records, as well as the occurrence of the TL and TW maximum values recorded for the species captured in the Tarumã river. Statistical tests were performed using the R-package (21) with significance of $p<0.05$.

\section{RESULTS}

The LWR was estimated from 343 specimens belonging to thirteen species, seven families and two orders (Table 1). The linear regressions were significant $(\mathrm{p} \leq 0.001)$. The $\mathrm{R}^{2}$ varied from 0.91 in Boulengerella cuvieri to 0.99 in Brycon amazonicus. The intercept $a$ varied from 0.0045678 in $B$. amazonicus to 0.0798564 in B. cuvieri (mean $0.0422121 \pm 0.0532370)$. The value of $b$ varied from 1.36 in Leporinus friderici to 3.30 in B. amazonicus (mean $2.33 \pm 1.37$ ). The specie Colossoma macropomum had an isometric growth pattern $(b=3.09)$ (Table 1$)$.

\section{DISCUSSION}

The new LWRs for 2 species, new maximum weight for 4 species and maximum sizes recorded for 3 species highlight the scarcity of information on biological aspects of Amazon fishes. The allometric coefficients of the L. friderici, B. cuvieri, Prochilodus nigricans, Myloplus lobatos, Myloplus rubripinnis and Serrasalmus rhombeus species are not among the values (2.7-3.5) described by Froese (16). Factors such as habitat, area, seasonality, degree of stomach repletion, sex ratio, health, sample size, reproductive stages and preservation methods, could justify the values not in line with that proposed by Froese (16) $(22,23,24)$. These results can provide information for the FishBase as well as important data for the management of icthyofauna and conservation of the Tarumã River Basin. 
Table 1. Descriptive statistics and length-weight relationship parameters for 13 fish species, Tarumã River, Jaru Biological Reserve, Amazon. New length-weight relationships $(*)$, maximum total weight $(\dagger)$ and maximum total length ( ${ }^{\circ}$ ). Systematic positions were based on Nelson et al. (2016).

\begin{tabular}{|c|c|c|c|c|c|c|c|c|}
\hline \multirow{2}{*}{ Order/Family/species } & \multirow[b]{2}{*}{$\mathbf{N}$} & \multicolumn{2}{|c|}{ TL (cm) } & \multicolumn{2}{|c|}{ TW (g) } & \multicolumn{3}{|c|}{ Regression parameters } \\
\hline & & Min. & Max. & Min. & Max. & a & b $(95 \%$ CL $)$ & $\mathbf{R}^{2}$ \\
\hline \multicolumn{9}{|l|}{ Characiformes } \\
\hline \multicolumn{9}{|l|}{ Anostomidae } \\
\hline Leporinus friderici (Bloch, 1794) & 15 & 21.7 & 35.1 & 250.2 & 545.3 & 0.0245678 & $1.36(1.23$ to 1.55$)$ & 0.92 \\
\hline \multicolumn{9}{|l|}{ Bryconidae } \\
\hline Brycon amazonicus (Spix \& Agassiz, 1829) ${ }^{\dagger}$ & 19 & 23.5 & 60.2 & 135 & 2950.2 & 0.0045678 & $3.30(3.15$ to 3.57$)$ & 0.99 \\
\hline \multicolumn{9}{|l|}{ Ctenoluciidae } \\
\hline Boulengerella cuvieri (Spix \& Agassiz, 1829) & 22 & 24.7 & 84.1 & 650.1 & 4035.5 & 0.0798564 & 1.85 (1.56 to 2.10$)$ & 0.91 \\
\hline \multicolumn{9}{|l|}{ Cynodontidae } \\
\hline Hydrolycus armatus (Jardine, 1841) & 27 & 32.5 & 65.3 & 380.3 & 2501.3 & 0.0197435 & 2.95 (2,47 to 3.17$)$ & 0.92 \\
\hline Hydrolycus tatauaia Toledo-Piza, Menezes \& Santos, 1999 & 25 & 28.1 & 35.2 & 481.3 & 839.1 & 0.0387431 & 2.80 (2.49 to 3.20$)$ & 0.96 \\
\hline \multicolumn{9}{|l|}{ Prochilodontidae } \\
\hline Prochilodus nigricans Spix \& Agassiz, 1829 & 23 & 9.5 & 35.2 & 50.1 & 820.0 & 0.0261234 & 2.17 (1.98 to 2.50$)$ & 0.93 \\
\hline \multicolumn{9}{|l|}{ Serrasalmidae } \\
\hline Colossoma macropomum (Cuvier, 1816) & 27 & 34.2 & 64.5 & 1500.0 & 10150.3 & 0.0234781 & 3.09 (2.87 to 3.22$)$ & 0.92 \\
\hline Myloplus lobatus (Valenciennes, 1850) & 24 & 16.0 & 31.2 & 280.2 & 320.3 & 0.0465211 & 2.18 (1.87 to 2.34$)$ & 0.90 \\
\hline Myloplus rubripinnis (Müller \& Troschel, 1844) & 28 & 15.4 & 39.2 & 150.2 & 1643.2 & 0.0123121 & 1.78 (1.55 to 2.02$)$ & 0.96 \\
\hline Myloplus torquatus (Kner, 1858) ${ }^{+, * \cdot}$ & 51 & 16.4 & 34.6 & 268.0 & 1050.0 & 0.0134521 & 3.27 (3.01 to 3.48$)$ & 0.93 \\
\hline Serrasalmus compressus Jégu, Leão \& Santos, $1991^{\dagger} \cdot$ & 30 & 6.5 & 26.3 & 4.5 & 613.2 & 0.0128943 & 3.29 (2.98 to 3.60$)$ & 0.96 \\
\hline Serrasalmus rhombeus (Linnaeus, 1766$)^{\circ}$ & 52 & 19.0 & 46.4 & 260.0 & 1573.2 & 0.0266721 & 2.39 (2.03 to 2.69$)$ & 0.97 \\
\hline \multicolumn{9}{|l|}{ Siluriformes } \\
\hline \multicolumn{9}{|l|}{ Auchenipteridae } \\
\hline Ageneiosus inkermis (Linnaeus, 1766) & 15 & 23.3 & 50.5 & 202.2 & 270.2 & 0.0387322 & 2.68 (2.23 to 2.87 ) & 0.93 \\
\hline
\end{tabular}

\section{Conflict of interest}

There is no conflict of interest

\section{Acknowledgements}

We are grateful to the staff members of the ICMBio for their financial support and technical assistance in the fieldwork and Universidade Federal de Rondônia for their laboratory support.

\section{REFERENCES}

1. Bernard E, Penna LAO, Araújo E. Downgrading, downsizing, degazettement, and reclassification of protected areas in Brazil. Conservation Biology. 2014; 28(1):939-950. D0I: https://doi. org/10.1111/cobi.12298

2. Peres CA. Why we need megareserves in Amazonia. Conservation Biology. 2005; 19(1):728733. DOI: https://doi.org/10.1111/j.1523-1739.2005.00691.x 
3. Veríssimo A, Rolla A, Souto Maior APC, Monteiro A, Brito B, Souza C, et al. Áreas protegidas na Amazônia Brasileira: Avanços e Desafios. 1a edição. São Paulo: Imazon/ISA; 2011. URL: https:// imazon.org.br/areas-protegidas-na-amazonia-brasileira-avancos-e-desafios-2/

4. Bruner AG, Gullison RE, Rice RE, Da Fonseca GA. Effectiveness of parks in protecting tropical biodiversity. Science. 2001; 291(5501): 125-128. DOI: https://doi.org/10.1126/ science.291.5501.125

5. Frederico RG, Zuanon J, De Marco Jr P. Amazon protected areas and its ability to protect streamdwelling fish fauna. Biological Conservation. 2018; 219(1):12-19. https://doi.org/10.1016/j. biocon.2017.12.032

6. Reis RE. Conserving the freshwater fishes of South America. International Zoo Yearbook. 2013; 47(1):65-70. DOI: https://doi.org/10.1111/izy.12000

7. Reis RE, Albert JS, Di Dario F, Mincarone MM, Petry P, Rocha LA. Fish biodiversity and conservation in South America. Journal of Fish Biology. 2016; 89(1):12-47. DOI: https://doi.org/10.1111/ jfb.13016

8. Queiroz LJ, Torrente-Vilara G, Ohara WM, Pires THS, Zuanon J, Doria CRC. Peixes do Rio Madeira. 1ํㅡ edição. São Paulo: Dialeto Latin American Documentary; 2013.

9. Perin L, Shibatta OA, Bernarde PS. Fish, Machado River basin, Cacoal urban area, state of Rondônia, Brazil. Check list. 2007; 3(1):94-97. http://dx.doi.org/10.15560/3.2.94

10. Casatti L, Pérez-Mayorga MA, Carvalho FR, Brejão GL, Costa ID. The stream fish fauna from the rio Machado basin, Rondônia State, Brazil. Check list. 2013; 9(1):1496-1504. http://dx.doi. org/10.15560/9.6.1496

11. Costa ID, Ohara WM, Almeida M. Fishes from the Jaru Biological Reserve, Machado River drainage, Madeira River basin, Rondônia State, northern Brazil. Biota Neotropica. 2017; 17(1):1-9 . DOI: https://doi.org/10.1590/1676-0611-BN-2016-0315

12. Freitas TMS, Prudente BS, Fontoura NF, Montag LFA. Length-weight relationships of dominant fish species from Caxiuana National Forest, Eastern Amazon, Brazil. Journal of Applied Ichthyology. 2014; 30:1081-1083. DOI: https://doi.org/10.1111/jai.12436

13. Giarrizzo T, Oliveira RRS, Andrade MC, Goncalves AP, Barbosa TAP, Martins AR. Length-weight and length-length relationships for 135 fish species from the Xingu River (Amazon Basin, Brazil). Journal of Applied Ichthyology. 2015; 31(1):415-424. https://doi.org/10.1111/jai.12677

14. Schmid K, Andrade MC, Jesus AJS, Araujo JS, Santos PRB, Giarrizzo T. Length-Weight Relationships for Fish Fauna from Waterbodies in the Upper Tapajos River Basin of Palito Mountain Ridge, Brazilian Amazon Region. Biota Amazônica. 2015; 59(1):112-114. DOI: https://doi. org/10.18561/2179-5746/biotaamazonia.v5n3p112-114

15. Beyer JE. On length-weight relationships computing the mean weight of the fish of a given length class. Fishbyte.1987; 59(1):11-13. 
16. Froese R. Cube law, condition factor and weight-length relationships: history, meta-analysis and recommendations. Journal of Applied Ichthyology. 2006; 22(1):241-253. https://doi. org/10.1111/j.1439-0426.2006.00805.x

17. American veterinary medical association. Report of the AVMA panel on euthanasia. Journal of the American Veterinary Medical Association. 2001; 218(1):669-696. URL: https://avmajournals. avma.org/toc/javma/218/5

18. Le Cren ED. The length - weight relationship and seasonal cycle in gonad weight and condition in the perch (Perca fluviatilis). Journal Animal Ecology. 1951; 20(1):201-219.

19. Vanzolini PE. Métodos estatísticos elementares em sistemática zoológica. 1a edição. São Paulo: Ed. Hucitec; 1993.

20. Froese R, Pauly D. FishBase (version Feb 2018). In: Roskov Y. Ower G, Orrell T, Nicolson D, et al, editors. Species 2000 \& ITIS Catalogue of Life. 2019 Annual Checklist (Digital resource at www. catalogueoflife.org/annual-checklist/2019. Vol.1. 1ª ed. Leiden: Naturalis; 2019.

21. R Development core team. R: a language and environment for statistical computing, Version 3.5.2. [Internet]. 2019. URL Disponible en: http://www.r-project.org

22. Miranda R, Galicia D, Monks S, Pulido-Flores G. Weight-length relationships of some native freshwater fishes of Hidalgo State, Mexico. Journal of Applied Ichthyology. 2009; 25(1):620621. https://doi.org/10.1111/j.1439-0426.2009.01319.x

23. Hossain MY, Rahman MM, Fulanda B, Jewel MAS, Ahamed F, Ohtomi J. Length-weight and length-length relationships of five threatened fish species from the Jamuna (Brahmaputra River tributary) River, northern Bangladesh. Journal of Applied Ichthyology. 2012; 28(1): 275277. https://doi.org/10.1111/j.1439-0426.2011.01900.x

24. Hossain MY, Sayed SRM, Mosaddequr Rahman M, Ali MM, Hossen, MA, Elgorban AM, Ohtomi J. Length-weight relationships of nine fish species from the Tetulia River, southern Bangladesh. Journal of Applied Ichthyology. 2015; 31:967-969. https://doi.org/10.1111/jai.12823 